\section{苏格兰邓巴炮台历史遗迹再生设计 REGENERATION DESIGN OF THE HISTORIC DUNBAR BATTERY IN SCOTLAND}

\section{1 项目背景}

1781年，由于美国舰船曾试图突袭邓巴镇港口，苏格兰人民在拉 默岛上建造了一座炮台以抵御外敌人侵和海盗袭击。当时炮台上的围 墙和射击孔、一系列拱形弹药库和样式丰富的地表铺装均被保留了下 来。1874年, 当地居民在防御墙的东侧建起一座两层高的隔离医院。 这座医院于1906年关闭，但在1914年重新开放，以收容第一次世界大 战期间的伤员。1927年, 医院再度关闭。此后, 炮台被用作临时住 房, 直到20世纪30年代中期其屋顶被炸毁，这座建筑才被最终拆除，留 下了一处面积较大的空地和一处面积较小、原为熏蒸室的围合空间。

场地丰富的历史背景和使用印迹对各项设计的布局和形式产生了 深刻影响。例如, 圆形剧场的木质平台选址在医院遗址中的空地, 平 台所使用的木材质地也与医院病房的木地板相互呼应。设计师还新建 了一条从港口通向炮台的小径, 并沿途设计了一条时间轴线, 向游人 讲述着炮台的往昔岁月。
克里斯 ·兰金

Rankinfraser景观设计事务所合伙人; 英国爱丁堡大学建筑与 景观设计学院讲师
摘要

本项目的设计对象是位于苏格兰邓巴海港区 拉默岛上的一座石砌炮台遗迹。Rankinfraser 景观设计事务所作为项目的总领导者, 通过妥善 协调设计团队、项目委托方与公众之间的关系， 在从前期场地调研到建设资金及许可申请等一系 列工作中展现了出色的专业水平。项目秉持迪 特 ·拉姆斯的至简设计理念, 在尊重场地原貌的 前提下对其进行全面、深入的特征信息挖掘, 最 境教育、娱乐集会等多种功能为一体的市民空 间。自2017年建成以来, 当地公众与景观设计行 业均对其给予了积极评价。

\section{关键词}

景观设计；多层次历史遗迹；公共艺术；再生； 社区；景观服务 终将炮台打造为一个集公共艺术、历史诠释、环

\section{Chris RANKIN*}

Partner of Rankinfraser Landscape Architecture; Lecturer in School of Architecture and Landscape Architecture, University of Edinburgh

*Corresponding Author

Address: 8 Darnaway Street, Edinburgh EH3 6BC Email: chrisrankin@rankinfraser.com

\section{ABSTRACT}

The project is for the design of a new civic space within Lamer Island Battery, a stone defensive structure built on a rocky outcrop in Dunbar Harbour, Scotland. Rankinfraser Landscape Architecture was employed to provide professional design services from early site research to helping secure funding and permit application as the primary leader of coordination among the design team, the client, and the public. Based on a Dieter Rams' principle that "good design is as little design as possible," the design prioritises the importance of site along with a detailed and thorough understanding of the components that constitute the character of the place, providing new public art, deeper interpretation of the site's history, environment education, and attractive places for gathering. Since its completion in 2017 the battery has been very well received, both by the local communities and professionals.

\section{KEY WORDS}

Landscape Architecture; Palimpsest of History; Public Art; Regeneration; Community; Landscape Service
编辑 王胤瑜 翻译 刘姝 田乐

EDITED BY WANG Yinyu TRANSLATED BY LIU Shu Tina TIAN 


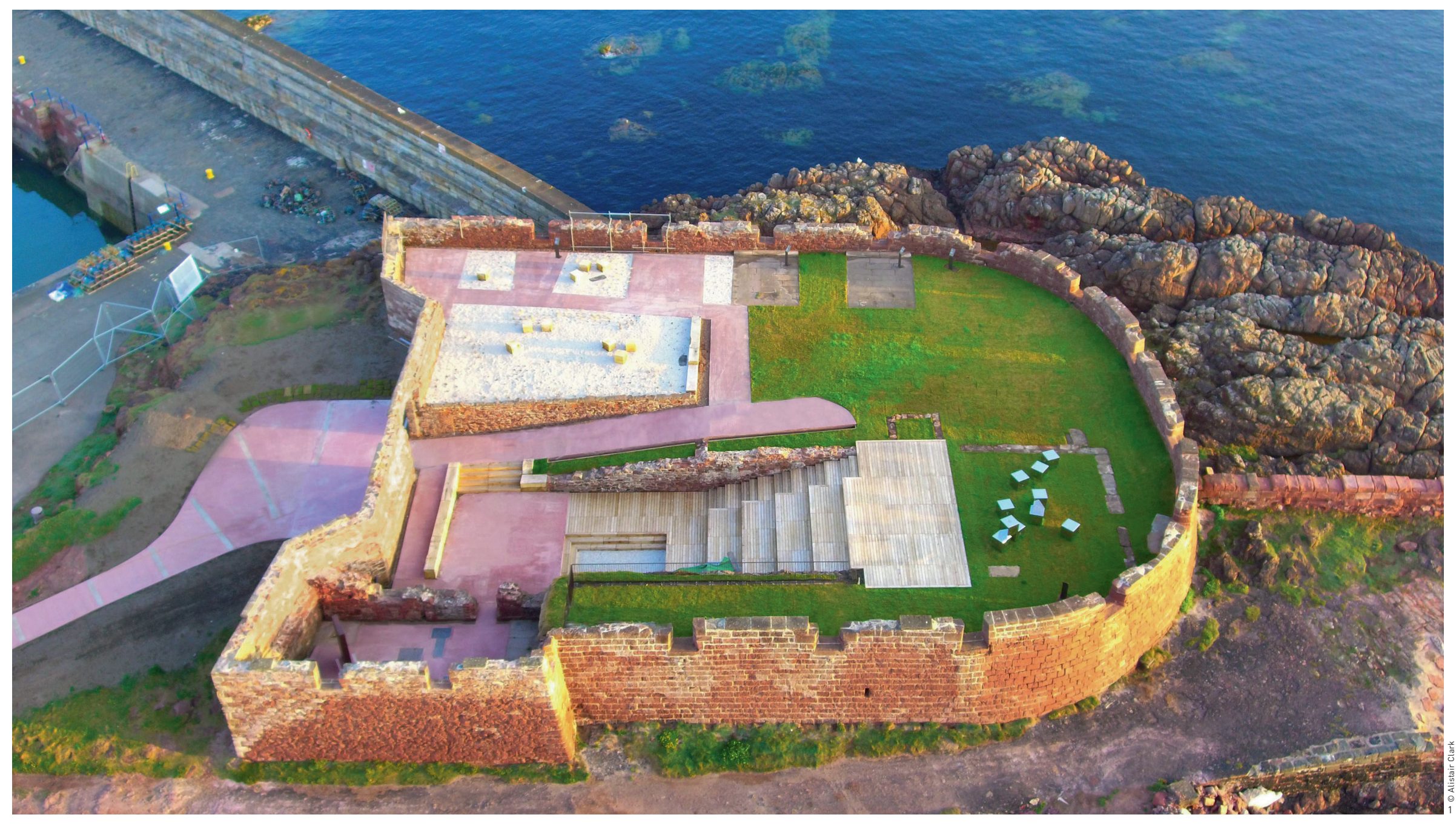

\section{2 设计过程}

\section{1 景观设计师的角色}

作为主要顾问团队, Rankinfraser景观设计事务所参与了从设计到 交付的全部项目阶段，包括提出初始概念设计与深化设计、起草任务 书, 以及按照传统委托模式进行施工监理等, 并协助客户筹集主要资 金, 以及申办规划许可、文物保护建筑改造许可、广告许可、建筑许 可等必要法律文件。作为整个设计团队的领导者, Rankinfraser景观设 计事务所还负责协调所有的顾问资源，并与主承包商和各专业分包商 密切合作。

在可行性研究阶段, 设计团队与委托方一邓巴港口信托基金会 共同确定了 4 个主要设计目标: 1 ) 改善场地内部及周边的道路设计, 使之适合各年龄段游客及行动障碍人士通行；2）修复和保护石造遗迹
及其他历史元素；3）将场地打造为海港目的地, 以促进当地旅游业发 展和经济复兴；4）创建一处可举办当地集会和音乐会的多用途表演空 间。与该项目相关的另一个小型项目一一古船螺旋桨修复项目一也 由Rankinfraser景观设计事务所负责。

\section{2 预算}

2015年，该项目成功向Viridor公司申请到70万英镑的项目资金。另 外，苏格兰历史环境部还为炮台提供了 5 万英镑的基础维修专项资金。 该项目共募得 75 万英镑, 其中 49 万英镑用于炮台项目的建造, 6 万用于 古船螺旋桨修复项目。

\section{3 设计}

炮台的设计充分展现了场地的多重历史魅力, 以场地内层次丰 

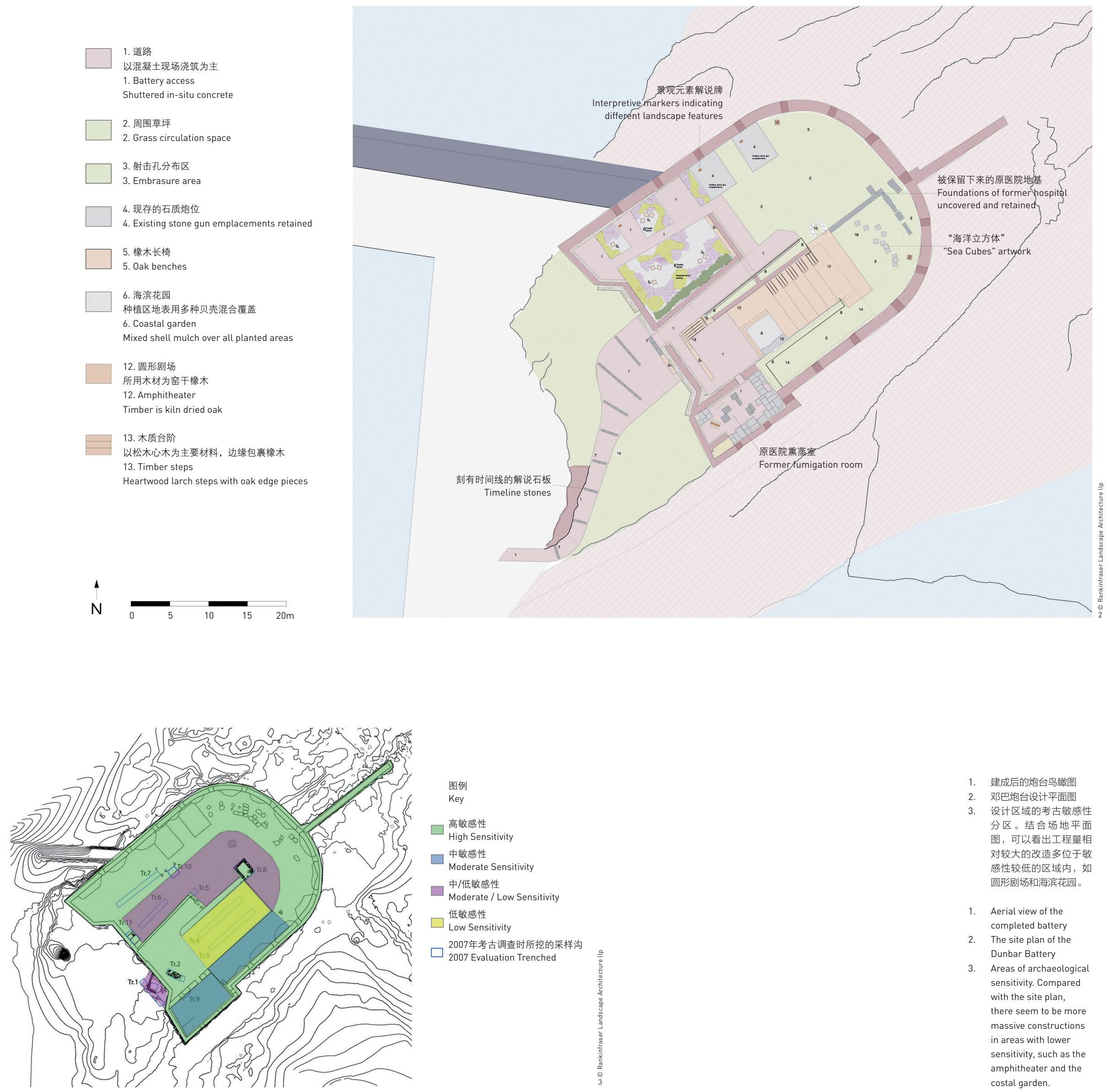

2. 邓炮台设计平面图

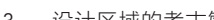

分区。结合场地平面

图, 可以看出工程量相 对较大的改造多位于敏 感性较低的区域内, 如

Aerial view of the completed battery The site plan of the
Dunbar Battery

3. Areas of archaeological sensitivity. Compared with the site plan, $m$ to be more in areas with lower amphitheater and the costal garden. 
富的历史印迹为依据来确定具体设计形态与位置。新的设计并非旨在 与原有历史建筑形成鲜明对比或全盘取代历史建筑, 而是力求突出现 有空间特色, 并将场地转变为多功能的公共空间。设计团队首先了解 场地的重要景观特征, 然后在此基础上引人新的构筑元素, 形成对现 有场地的一种补充。例如, 该项目中最重要的新增构筑物一一圆形剧 场即是利用原医院的断壁残垣形成新的围合空间，既保持了医院的历 史印迹, 又使人们的视线不受遮挡。设计也没有刻意打破场地原有格 局, 而是有意识地与炮台原有结构及其独特的周边环境相协调: 以橡 木、松木及混凝土等材料为主的元素简约而富有活力, 与开放的空间 形态相得益彰, 丰富了以石墙为主的原有场地景观; 特制的金属网栅 栏既体现了高品质的设计细节，又保证了场地的通透视野。

邓巴炮台及港口均归邓巴港口信托基金会所有，作为慈善组织, 该基金会致力于提升社会福祉及增加娱乐休闲设施、为港口增加新的 使用方式、发展公共教育, 以及通过港口营运为邓巴当地居民及更广 泛的公众带来更多效益。作为对基金会目标的响应, 该港口再生项目 在保留炮台建筑遗迹的同时创建了全新的公共集会空间, 促进了当地 教育及公共艺术的发展, 并提高了港口可达性。

\section{4 可持续性与环境敏感性}

为了防止炮台上的构筑设施每况愈下, 并最终由于安全隐患而禁 止公众进人, 我们必须为这些历史遗迹注人活力, 使它们重焕新生。 在委托方与设计团队的共同努力下, 苃苃可危的炮台转变成了充满活 力的社区财富。设计团队首先对场地开展考古调查, 并以调查结果指 导各个阶段的设计, 对于在施工过程中新发现的历史遗迹元素也会积 极妥善处理。

该项目将场地保护措施与新的创新性公共艺术策略、长期公开演 出计划及社区的运营与管理工作相结合。由于该项目位于岛上, 且通 往场地的唯一通道桥有承重限制, 因此所有的建造材料都被拆分成小 部件进行运输。

\section{5 解说系统和视觉设计}

为了营造一处怡人殹意的休闲空间，设计团队之一的LR工作室采 用了一种低干预设计手法来打造炮台的景观解说系统。设计师选择了 一些形式朴素的元素, 如将《航运天气预报》广播节目中不列颠群岛 各海区的名称雕刻在木质台阶上, 以及在射击孔旁设置多个传统式眺 望点, 使游客得以观赏场地周边的景致。

项目整体的视觉设计风格也与场地地形特征相呼应, 并运用少量 的人为设计实现与自然材料的融合。这些设计手法与风格营造出了原 汁原味的场所感, 将人与场地历史及周围的环境联系起来, 并鼓励人 们在整个海港地区进行探索。

\section{6 海滨花园}

在与当地居民的交流中, 设计团队了解到他们希望拥有一座社
区花园; 在设计阶段, 设计团队将社区花园选址于炮台地势较高的区 域, 包括连接射击孔观景点的小径、一系列可供休㮩的实心橡木立方 体, 以及由当地社区负责日常维护的适量绿植。设计方案只规划了绿 植的原始布局, 允许其随着时间的推移而不断演变。

\section{7 以充满想象力的方式吸引利益相关者参与}

通过建立专门的网站用于收集各方意见并及时告知当地居民项 目进展, 项目实现了全面且持续的社区参与。此外, 项目团队还邀请 苏格兰艺术家唐纳德 - 乌尔克哈特专门为场地创作了一项当代艺术装 置一一海洋立方体”, 作为该项目的一大亮点。当地还同期开展了一系 列介绍与校园参与活动, 并举办了一场公开展览, 展示了当地小学生 制作的浮游生物丝网版画以及乌尔克哈特新近创作的其他艺术作品。

\section{8 艺术装置 “海洋立方体”}

乌尔克哈特的创作实践广受国际赞誉, 苏格兰几处主要的公共艺 术作品都出自他之手。“海洋立方体” 造型的灵感来自于立方体状的 海盐晶体 (代表东洛锡安地区历史上的晒盐产业) , 且与炮台围墙上 射击孔的形状相呼应。在该装置作品中, 立方体的反射面位置根据炮 台的朝向精心设计, 使阳光能够被反射到炮台的人口处; 装置的上表 面则反射出天空, 形成 11 个反射面。镜面不锈钢材质使装置融人周围 环境，在环境和观者之间产生丰富多变的互动。

除了与炮台环境相呼应, 这项艺术装置也有意识地与广阔的海洋

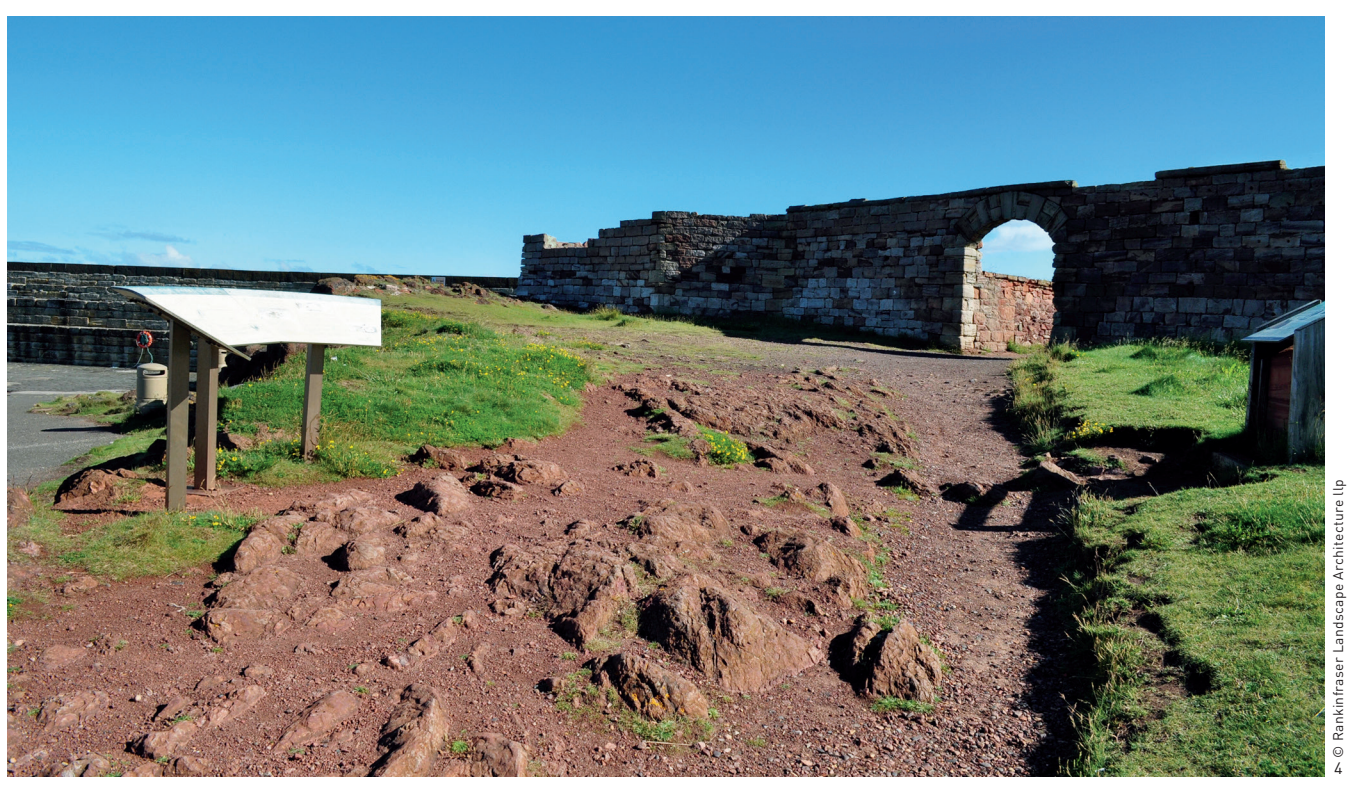


形成对比, 使游客可以从微观视角观察海水及海洋生物。立方体的表 面用机器雕刻了 22 种当地浮游生物, 包括螃蟹、龙虾和对虾等常见 的渔业品种。这些雕刻图像依据苏格兰环境保护局提供的照片绘制 而成。

每个 “海洋立方体” 的宽度为 $0.6 \mathrm{~m}$, 可作为非正式的座椅使用。 由于装置所在区域地势较高, 人们可在这里眺望大海或观看圆形剧场 的演出活动。

这项富有环境教育意义的艺术装置还致力于引导人们关注海洋食 物链的基础。在装置创作期间, 项目团队定期在周边社区开展咨询活 动, 并在其建成后为当地学生举办了一系列版画制作讲习班。

\section{3 评估和反馈}

\section{1 社区参与与咨询}

在该项目中，富有远见的设计师依靠社区参与以及必要的项目 投资，使炮台遗迹焕然一新，并在社区中赋予其新的功用，使其迸发 出勃勃生机。项目团队始终致力于将港口变为一项对当地居民和游客 充满吸引力的资产, 并尽可能地发掘其作为港口地标的最大潜力。在 2014年春天项目启动之初, 设计团队即开展了对港口游客的调查, 以 及针对当地居民的在线问卷调查等社区咨询工作，为炮台后续改善项 目的开展提供参考。

社区调查收集到的需求反馈主要包括：1）希望炮台继续免费对 外开放; 2 ) 改善道路条件, 解决因铺装材料松散而造成的路面不平问 题；3）修复炮台现有的基础结构, 但不必完全依原貌恢复；4）增加 必要的解说和可观赏的元素。

该项目设计具有较高的效益和可持续性, 且维护成本较低, 与 场地游客量和其所在的滨海环境相匹配; 既拥有鲜明的当代特征, 又 展现了原有建筑及在项目推进过程中逐步被发掘出来的历史遗迹的魅 力。项目团队会随时调整设计策略, 以呈现施工过程中的新发现。作 为成功复兴港口地区和炮台再生的催化剂, 设计不仅考虑了未来 50 年 的使用需求, 也为炮台发展的不确定性预留了调整余地。

\section{2 社区活动和网站 ${ }^{(1)}$}

当地民众对炮台改造项目予以一致好评，自建成以来，参观港口 的人数大大增加, 人们在场地中的逗留及休㮩时间也更长。邓巴港口 信托基金会鼓励当地团体在邓巴炮台进行表演和开展活动。2017年夏 季, 场地迎来了荷兰青年管弦乐团的巡回演出, 吸引了不同年龄段的 观众; 而同年 12 月在此举办的颂歌音乐会也有超过 200 人参与演出。 2018年，邓巴港口信托基金成立了一个名为 “邓巴炮台之友” 的社区 小组, 致力于开发炮台的潜在功能, 目前已经初步预定了未来一年内 的8项活动, 并邀请本地、东洛锡安地区和全国范围内的其他活动进 驻, 以使更多人感受到邓巴炮台的独特魅力。除了音乐会和颂歌演出 之外, 许多当地人也选择在这里举办婚礼。
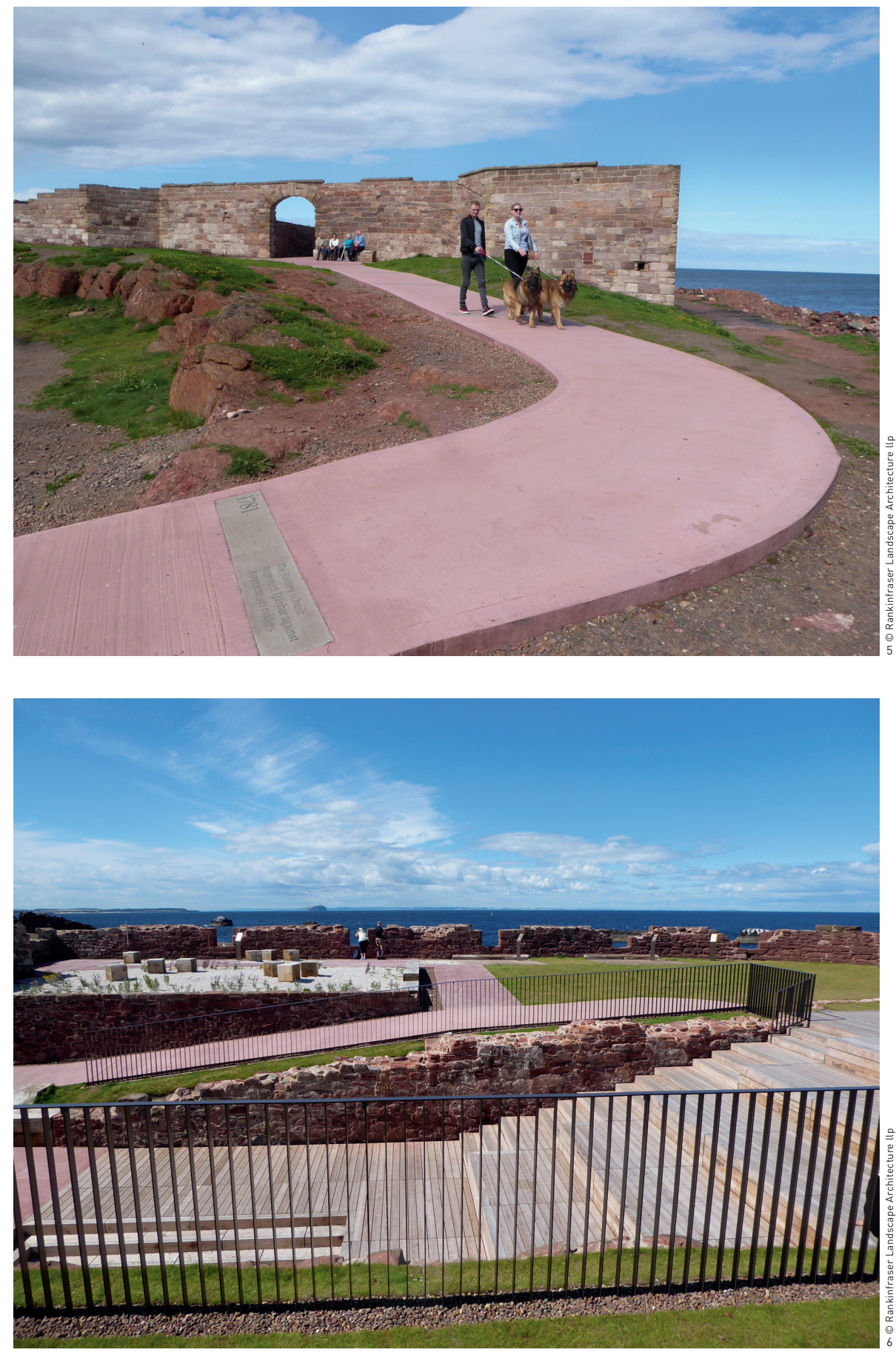
有关邓巴炮台的更多 背景信息与活动介 绍, 请访问https:// dunbarbattery.org.uk。
4. 改造前的炮台入口区域 5. 改造后的炮台入口处道路 6. 在炮台高处越过栏杆向北 方眺望的视野




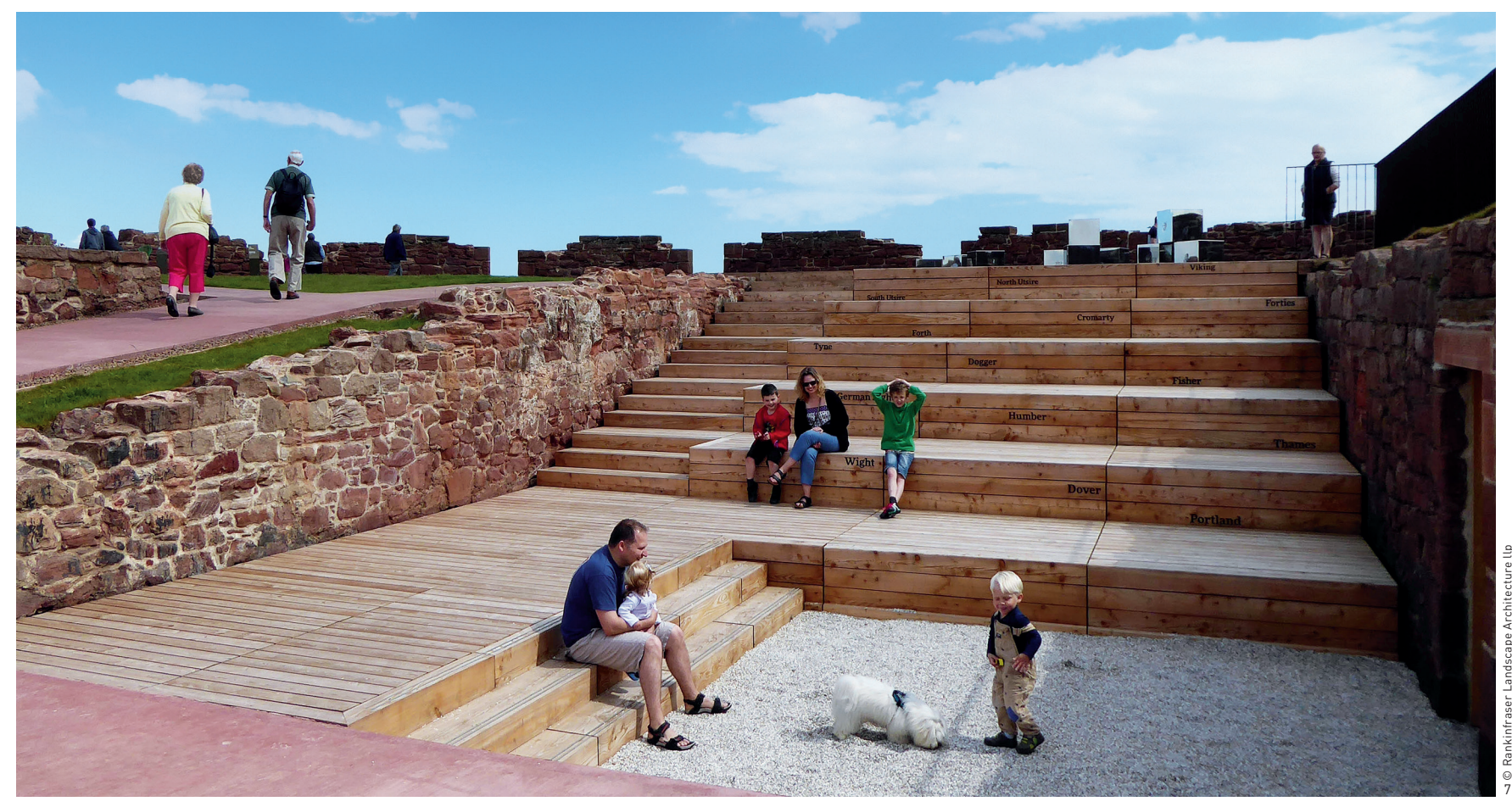

\section{3 其他社会效益}

改造后的炮台项目不仅越来越受到当地居民的喜爱，也吸引了众 多外地游客, 成为继约翰 - 缪尔故居博物馆、邓巴城堡和海港之后一 个新的旅游热点。在该项目建成之前，在炮台的封闭空间内曾发生过 一些反社会行为, 而在项目建成之后, 由于人流量的增加、空间转型 以及当地人对于场地认同感的增强, 类似的行为已极少发生。

\section{4 反思}

邓巴炮台项目的设计范围和复杂性提供了一个全面展示景观设计 师专业能力的绝佳机会：设计团队首先充分挖掘场地的潜力、了解委 托方对场地未来的期望，并根据委托方的意见，不断对前期设计方案 进行检验和调整，随后根据初步方案来募集资金并争取外界支持。此 外，团队努力控制前期工作成本，使项目能够有序推进。

团队始终从专业角度秉持广泛的社会和环境责任意识，致力于尊 重和提升炮台的历史重要性，使其能够惠及当地所有社区。新增的当 代设计元素都遵循德国著名工业设计师迪特 - 拉姆斯提出的 “至简为 上” 原则, 以实现更广泛的服务目标：例如，新设计的道路在形式上 尽可能质朴, 又能与岩石地面明确区分开来; 选用通透性较高的新栏 杆；圆形剧场体量轻盈，与周围厚重的石墙互为映衬。LAF

\section{项目信息}

项目地址: 苏格兰东洛锡安地区邓巴镇

项目面积: $0.1 \mathrm{hm}^{2}$

项目委托: 邓巴港口信托基金会

项目团队: Rankinfraser景观设计事务所（景观设计与首席顾问）；David Narro工程设计事务所（结构 与市政工程设计）；WGM工程设计公司（机械与电气工程设计）；LR工作室（解说系统设计）；Donald Urquhart（公共艺术装置创作）

设计时间: 2016年

建造时间: 2016年11月 2017年6月

所获奖项:

2017 《建筑学刊》建筑奖

2017 《建筑评论》旧建筑更新奖提名

2018《建筑学刊》“ “500万欧元以下文物保护建筑”更新设计类

2018景观设计学会奖 “小尺度开发设计” 类推荐项目

2018苏格兰市民信托基金会 “我的家乡” 推荐奖

2018英国市民信托奖区域类项目决赛入围项目

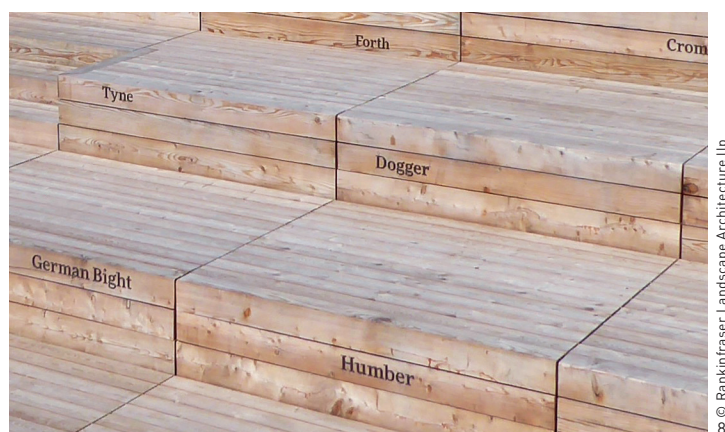

从表演区域观看圆形剧场 及远处的 “海洋立方体” 从炮台高处可以看到圆形 剧场的橡木台阶上所刻的 海区名称

7. View of amphitheater from performance area with "Sea Cubes" in the background

8. The routered names in the oak steps of the amphitheater seen from the upper level of battery 
9. 可以直接观赏到巴斯岩 的一处射击孔，旁边为 巴斯岩的解说牌。

10. 从海滨花园眺望邓巴 城堡

9. View from embrasure towards Bass Rock with its interpretation beside

10. View of coastal garden towards Dunbar Castle

\section{Background}

The battery on Lamer Island was built in 1781 to protect the Dunbar Town from invasion and privateers after an American ship attempted to raid the harbor. Remnants from that time include all of the perimeter wall and embrasures, a series of vaulted munitions stores, and various paved surfaces. In 1874 the structure was developed into an isolation hospital, a twostory building located to the east of the defensive walls. The hospital closed in 1906, but was re-opened in 1914 to house convalescing soldiers during the WWI. It remained a hospital until 1927 when it closed. The battery was then used as emergency housing until the mid-1930s when the roof blew off and the structure was finally dismantled. The removal of the hospital left a large void, and a smaller enclosed space thought to be a fumigation room.

This rich history and the traces of occupation left on site informed the location and form of the various design interventions. The timber surface of the amphitheater for example occupies the void left by the hospital building and the

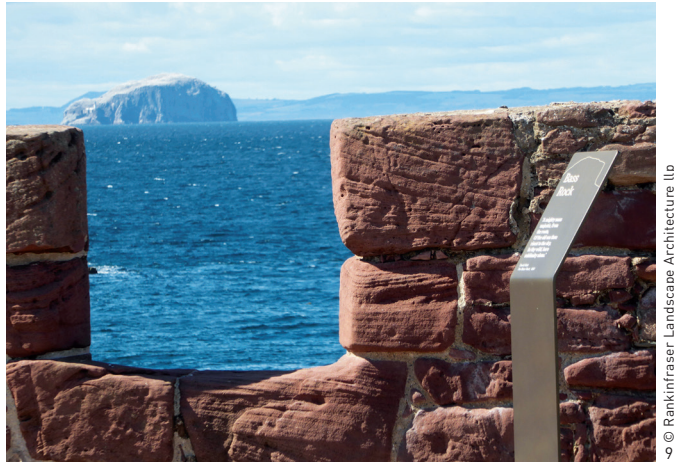

material of the deck echoes the timber flooring of the hospital wards. The intriguing history of the battery is told through an interpretive timeline set into the new path that leads visitors from the harbour up into the space.

\section{Design Process}

\subsection{Role of Landscape Architects}

Rankinfraser Landscape Architecture was the leading

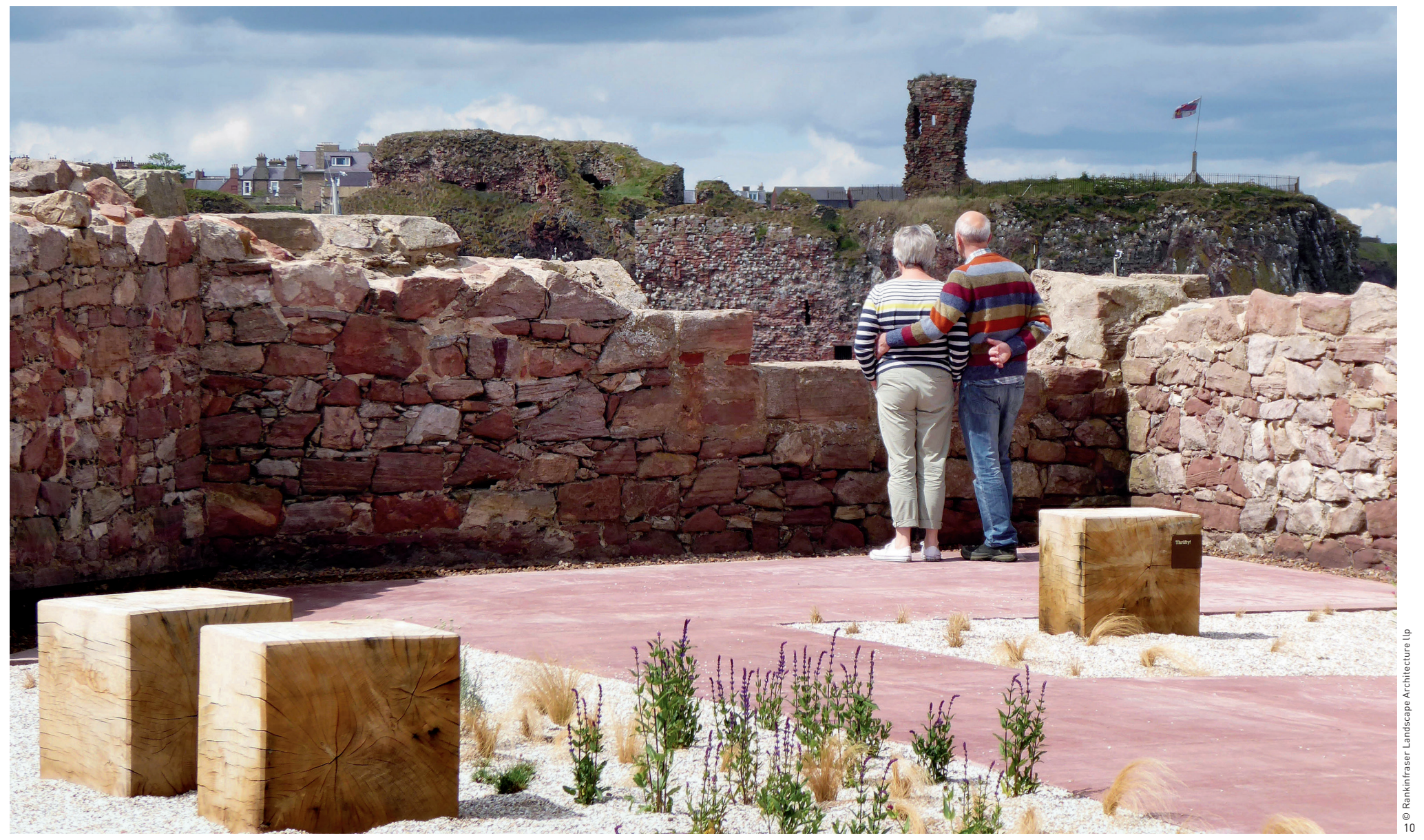


consultant for all stages of the design and delivery of this project. In this public space design, our work included from brief development through initial concepts and detailed design to supervision of the construction under a traditional contract. We aided the client in securing the bulk of the funding, managed all the statutory consent applications for Planning, Listed Building, and Advertising Consents, as well as the Building Warrant Application. We led the design team, ensuring coordination of all consultants' information, and worked closely with the main contractor and specialist sub-contractors.

The brief developed with the client Dunbar Harbour Trust during the feasibility study stage focused on four themes: 1) improved access to and within the battery for all ages and abilities; 2) the repair and conservation of the stonework and other historic elements; 3 ) the creation of a destination within the harbour to promote tourism and economic regeneration; and 4) the creation of a multi-purpose performance space for local gatherings and concerts. A smaller associated project to improve the setting of a historic ship's propeller was also undertaken by Rankinfraser.

\subsection{Budget}

A successful funding application to Viridor awarded the project 700,000 pounds in 2015. Funding of 50,000 pounds was also awarded by Historic Environment Scotland specifically for the repair of the battery fabric. The total project budget therefore was 750,000 pounds including a construction cost of 490,000 pounds for the battery project and 60,000 pounds for the improvements to the Ship's Propeller site.

\subsection{Design}

The battery design exploited the site's palimpsest, using the layers of history to inform and guide the design and distribution of various contemporary interventions. The inventions were not intended to compete with, or overpower, the historic structure. On the contrary, the design sought to amplify the existing spatial character whilst transforming the space into a multi-functioning public arena. As a practice we always seek to firstly understand the essential character of the landscape and only then add new tectonic layers that complement the existing site. For example, the most significant new structure, the amphitheater, is integrated into the void formed by the walls of the former hospital so as to leave the trace of the hospital untouched and the views unimpeded. The design purposely worked with the existing structure of the battery and the exceptional setting, and did not seek to compete with either. The robust and reduced material palette of oak, larch, and concrete responds to the exposed location and complements the existing stone walls in

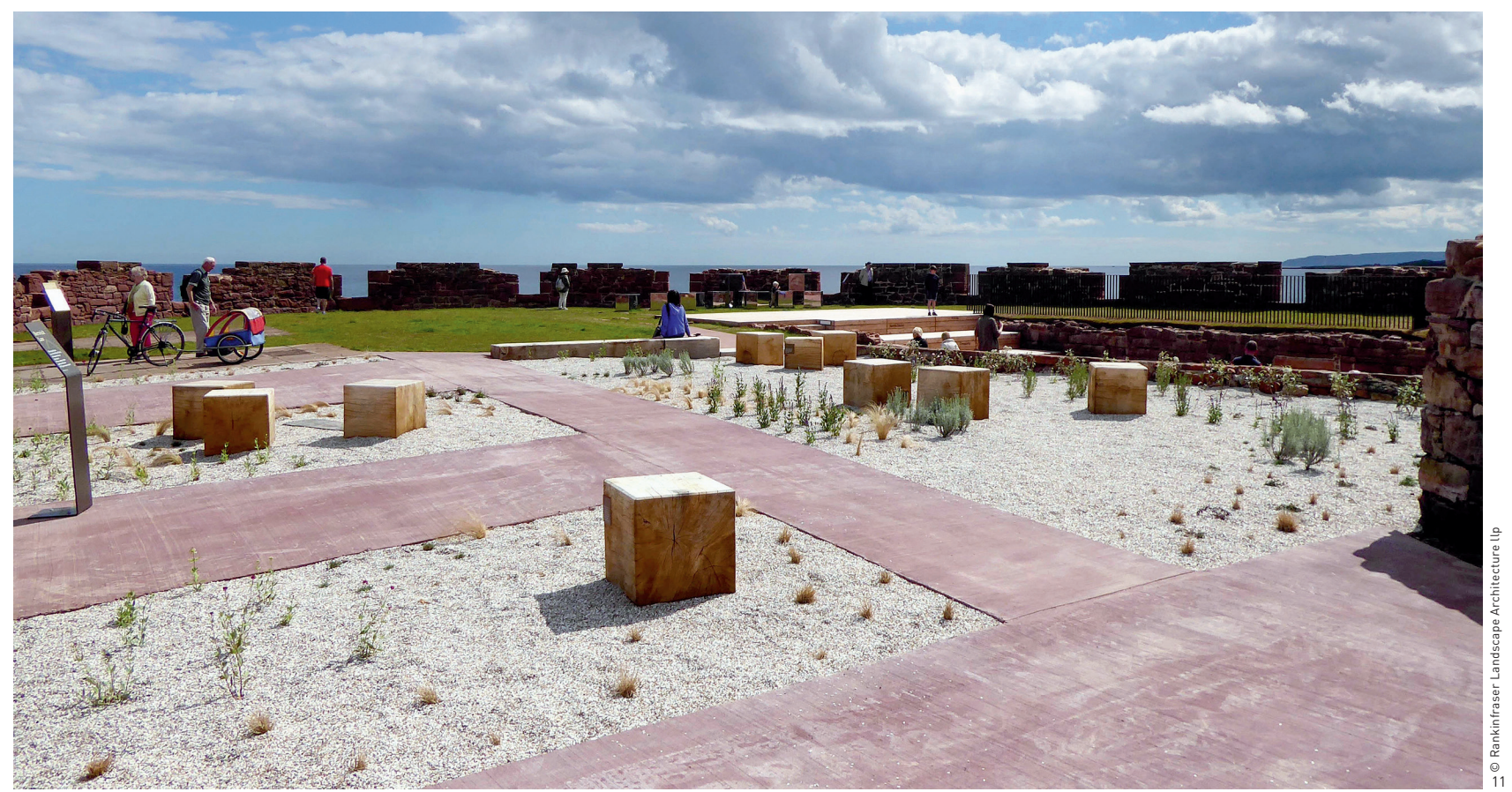


11. 海滨花园及其内部可供 休唕的实棉木立方体

. 在“海洋立方体”所在

的位置可以眺望炮台入

口及远处的邓巴城堡

11. The coastal garden and

oak cubes for sitting

within it

12. View of "Sea Cubes"

with the battery

entrance and the

Dunbar Castle behind

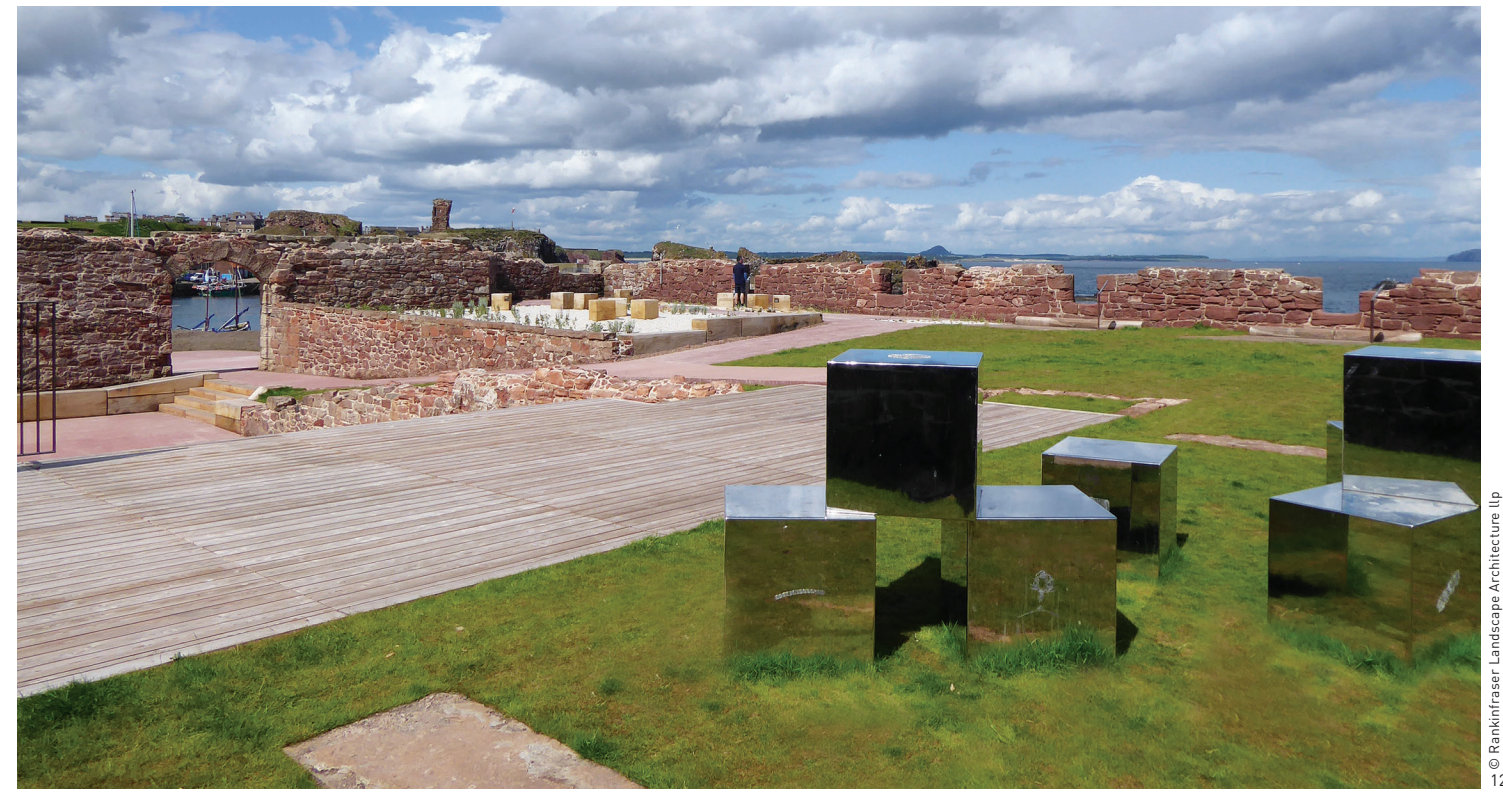

richness and texture. Bespoke metal palisades are deliberately delicate and transparent so as not to block views across the site.

The Dunbar Battery and the harbor are owned by the Dunbar Harbour Trust, a charity whose purposes include social welfare and recreation, attracting new uses to the harbor, public education, and operating the harbor for the locals' benefit of Dunbar and the wider public. The regeneration of the battery therefore represents a significant contribution to those aims through the creation of a new public gathering space that promotes education, public art, and easy access whilst conserving a Listed Building.

\subsection{Sustainability and Environmental Sensitivity}

The battery would have continued to deteriorate if a new life had not been found for the structure. Ultimately without interventions the site might have to be closed to public access due to safety concerns. That was prevented and the site turned from a potential liability into a positive community asset through the energy of the client and a wider design team. An archaeological investigation preceded and informed the design work at each stage. A responsive and sympathetic approach was taken to more elements of historic interest as they were uncovered during the course of construction.

The conservation approach was aligned to a new and innovative public art strategy, ongoing public performance programs, and community ownership and management. Because of the site located in an island and a weight limit on the only access bridge to the site, all materials had to be capable of delivery in small components.

\subsection{Interpretation and Graphic Design}

Studio LR adopted a light-touch approach to interpretation design, as this is a place for people to relax. There are some discreet elements such as the sea area names broadcast by Shipping Forecast routerred into timber steps, as well as more conventional look-out points to connect visitors with the best views of landmarks around the battery embrasures.

The graphic style is also understated leading with typography and minimal graphic elements embedded with natural materials. The aim is to give local people a true sense of place, as well as a connection with their past and surroundings, and to encourage exploration around the whole harbour area.

\subsection{Coastal Garden}

The desire for a community garden was identified during the community consultation and included in the final brief as part of the overall project. The garden was located in an upper area of the battery, consisting of an access to viewing points aligned on the embrasures, solid oak seating cubes, and appropriate planting to be maintained by the local community. An initial planting structure was implemented as part of the contract with the intention that evolves and develops over time. 


\subsection{Imaginative Ways of Involving Stakeholders}

Community engagement was thorough and continuous over the course of the project with a dedicated website to gather views and inform local residents of progress. A key component of the project was a site-specific contemporary artwork "Sea Cubes" by the Scottish artist Donald Urquhart. Parallel to the artwork project, a series of consultation events and a local school engagement program were undertaken culminating in a public exhibition of screen prints of planktons by Primary 7 pupils alongside new artworks by Donald Urquhart.

\subsection{Artwork - Sea Cubes}

Scottish artist Donald Urquhart has internationally recognized practice including several major public artworks across Scotland. The form of the cubes echos that of the embrasures in the battery walls and is derived from the cubic form of sea salt crystal (which alludes to salt panning, a historic industry of East Lothian). The reflective surface of the cubes makes sunlight a principal component of the work, with the orientation of the battery reflecting sunlight towards the entrance of the structure. The upper surfaces reflect the sky, creating eleven planes of light. The use of mirrored stainless steel creates a work that brings the surrounding environment into the work, producing a complex and shifting interactions between the environment and spectators.

Besides echoing the battery, the work is intended to contrast with the expanse of the sea seen from the battery with a microscopic view on seawater and the hidden life it contains. The forms of twenty-two species of local planktons have been machine-engraved on the cubes' surfaces, including the principal species caught by Dunbar fishing boats - crab, lobster, and prawn. These engraved images were drawn by Urquhart from photographs supplied by the Scottish Environmental Protection Agency.

With its visual dynamism the work is also designed as informal seating, which is why the cubes are $0.6 \mathrm{~m}$ in width. The location of these cubes within the battery allows them to be used for elevated views out to sea or towards events in the amphitheater.

There is an environmental intention to the work to draw attention to the base of the marine food chains. The work was developed with regular consultation events involving the communities. There was also an extensive set of printmaking workshops with local school students.

\section{Review and Feedback}

\subsection{Community Engagement and Consultation}

This project is an excellent example of how community engagement together with the required investment can, in the hands of people with the vision and skills to deliver an excellent design, rejuvenate interesting architectures and give them a new and joyous purpose in the community once again. We recognized our responsibility to transform the harbor into an

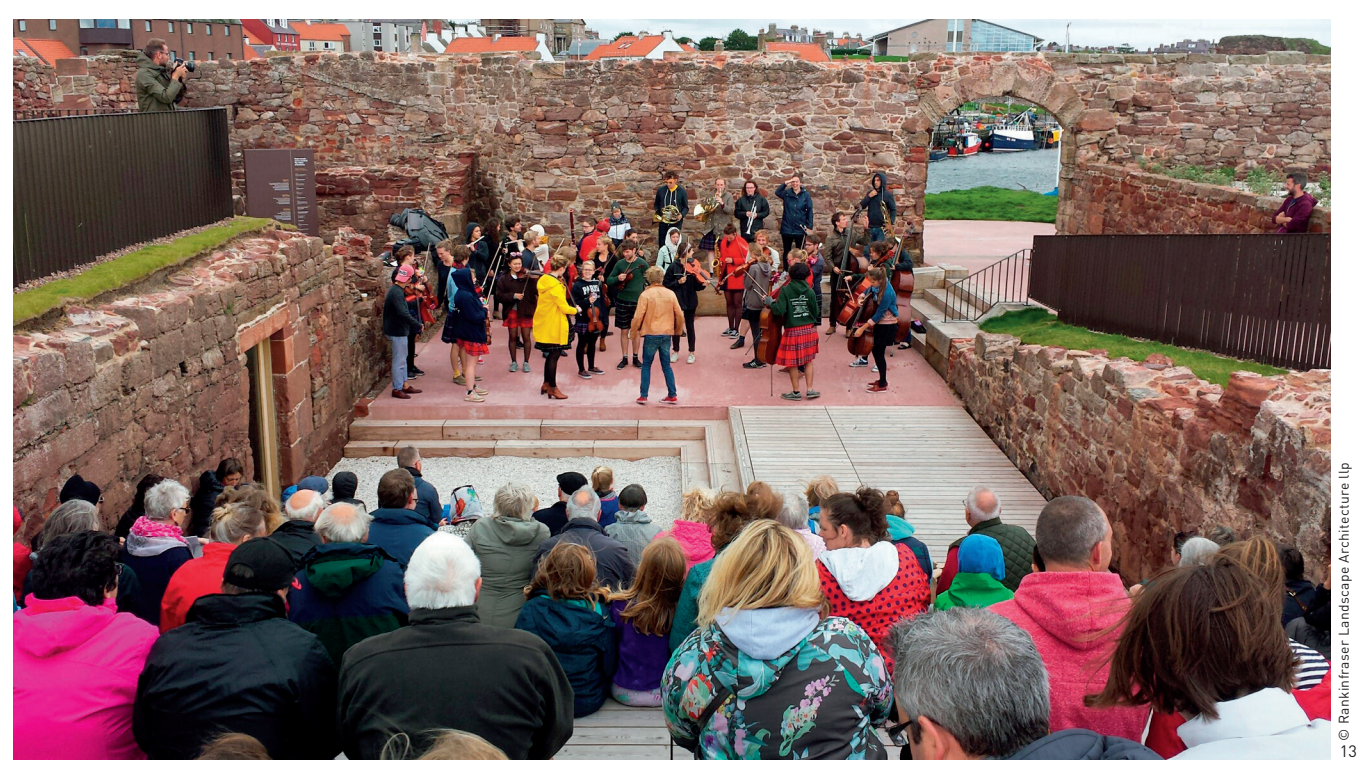
3. 在圆形剧场内举行的露 天演奏会
13. Outdoor concert in the amphitheater 
attractive asset for locals and visitors to the town but we had not been making the most of its interesting landmarks. The community was involved in this project from the beginning and we undertook a consultation period in the spring of 2014. This included carrying out a survey of harbor visitors and an online questionnaire to local residents and community, which helped us shape the brief for the improvement works to the battery.

The key points from the feedback included:1) to retain the open and free public access; 2) to improve the access, addressing the issues of the uneven path made from loose material; 3) to repair the existing fabric but not for a full restoration; and 4) to add a better interpretation system and more things to see in the battery.

The design team successfully delivered an attractive but robust landscape-based design with high benefits but low maintenance and appropriate for the number of visitors and the open coastal environment where it is located. It is of its age but sensitive to the old structure and the layers of history uncovered as the work progressed, and the design was adapted to make features of what we found. The work to the battery was a catalyst for successful improvements in the harbour and the rejuvenation of the battery not only meaning the structure is fit for purpose for the next 50 years but also the new features installed give the space a new role going forward.

\subsection{Community Events and Website ${ }^{\mathbb{1}}$}

The community feedback to the new battery has been unanimously positive, and since its completion in 2017 more visitors have been to the harbor staying longer to enjoy the area. The Dunbar Battery Trust has also encouraged local groups to use the Dunbar Battery for performance and events. In 2017, the summer highlight was around by the audience of all ages enjoying a touring youth orchestra from the Netherlands, while over 200 brave souls braved the elements for a carol concert in December. In 2018 the trust has set up a "Friends of Dunbar Battery" community group to work on developing use of the battery, and we have already provisionally booked eight events for the year ahead and are reaching out locally, regionally, and nationally to create more opportunities for all to enjoy the unique setting in Dunbar. Besides musical concerts and carol service, the battery has also become a sought-after wedding venue in the town.

\subsection{Other Social Benefits beyond Pleasure}

In addition to its increasing use by local people, the new battery plays an important role in attracting visitors to the town from further afield. It complements other visitor attractions in
Dunbar including the John Muir Birthplace Museum, Dunbar Castle, and the harbor. Before the completion of the project there was some anti-social behaviours occurring within the enclosed space of the battery. The increased footfall, transformation of the space, and the local identity with the space have reduced this significantly.

\subsection{Reflection}

The scope and complexity of the Dunbar Battery commission provides an opportunity for Rankinfraser to demonstrate the full extent of the professional services landscape architects can bring to a project. Initially we studied and understood both the potential of the site and the client's aspirations for what type of place this could become. The early design work was tested and adapted through review of the client. This initial design work then formed the basis of an application for funding for the project, also supported by us. Much of the early work was done on a limited fee to help the project move forward.

At every stage of the project we were aware that as design professionals we had a wider social and environmental responsibility to design a space that would respect and enhance the historic importance of the battery and serve all local communities. We achieved these aims by adding a new "layer" of contemporary design. Built upon Dieter Rams' principle that "good design is as little design as possible," this new layer is always in the service of the wider aims of the project. For example, the new path is as unobtrusive as possible whilst as a distinct layer sitting on the rocky ground, the new railings are as visually permeable as possible, and the amphitheater structure is deliberately of lighter construction than the surrounding stone walls. LAF

\section{PROJECT INFORMATION}

Location: Dunbar, East Lothian, Scotland

Area(size): $0.1 \mathrm{hm}^{2}$

Client: Dunbar Harbour Trust

Project Team: Rankinfraser Landscape Architecture (Landscape Designers and Chief Consultants); David Narro Associates (Structural and Civil Engineers); WGM (Mechanical and Electrical Engineers); Studio LR (Interpretation Designers); Donald Urquhart (Artist) Design Period: 2016

Construction Period: November, 2016 June, 2017 Awards:

Winner of Budget Project for AJ Architecture Awards 2017 Shortlist of Architectural Review "New into Old” Awards 2017 Winner of Listed Building Under Ł5m for AJ Retrofit Awards 2018 Highly Commended Design for a Small Scale Development of Landscape Institute Awards 2018 Commended "My Place Awards 2018" of Scottish Civic Trust Regional Finalist of Civic Trust Award 2018 